\title{
Strategies to control inbreeding in a pig breeding program: a simulation study
}

\author{
Jader Silva Lopes ${ }^{1 * 3}$ iD Paulo Roberto Nogara Rorato ${ }^{1}$ Fernanda Cristina Breda Mello $^{1}$ \\ Marcelo Silva de Freitas ${ }^{2}$ Alan Miranda Prestes ${ }^{1}$ Diogo Anastácio Garcia ${ }^{3}$ \\ Maurício Morgado de Oliveira ${ }^{1}$ iD
}

${ }^{1}$ Departamento de Zootecnia, Universidade Federal de Santa Maria (UFSM), 97.105-700, Santa Maria, RS, Brasil. E-mail: jadersilvalopes@gmail.com ${ }^{*}$ Corresponding author.

${ }^{2}$ Cobb-Vantress Inc., Siloam Springs, AR, USA.

${ }^{3}$ BRF S/A, Curitiba, PR, Brasil.

ABSTRACT: The objective of this study was to evaluate, through data simulation, the impact of restrictions on the maximum number of full-and half-sibs selected for males and females on the level of inbreeding and genetic gain of the herd. Data came from real populations $A$ and B, composed of Pietrain and Landrace breed pigs, respectively. To generate the simulated populations, a Fortran-language simulator was developed using the (co)variances of the breeding values and the productive and reproductive rates obtained from populations $A$ and B. Two data files were created. The first contained the pedigree of the previous 10 years, with 21,906 and 251,343 animals in populations A and $B$, respectively. The second included breeding values for age to reach $110 \mathrm{Kg}$ body weight, backfat thickness, and feed conversion, for both populations; longissimus dorsi muscle depth, for population A only; and number of live piglets at the 5th day of life per farrowing, for population B only. Three scenarios were simulated with ten generations by varying the restrictions on the number of full-and half-sibs selected for males and females, with 30 replicates per generation and scenario. Regardless of the mating strategy used in a closed production unit, there is an increase in inbreeding levels. Inbreeding increases are larger in populations of smaller effective size. Restrictions on the number of full- and half-sibs selected are effective in reducing increments in inbreeding. Restriction to a maximum of two full-sibs and three half-sibs for males and three full sisters for females provided the highest genetic gains.

Key words: full-sibs, half-sibs, Landrace breed, Pietrain breed, selection strategies.

Estratégias para controle de endogamia em um programa de melhoramento genético de suínos: um estudo de simulação

RESUMO: O objetivo deste estudo foi avaliar, por meio de simulação de dados, o impacto das restrições no número máximo de irmãos completos e meios-irmãos selecionados para machos e fêmeas no nível de endogamia e ganho genético do rebanho. Os dados originais são provenientes das populações reais $A$ e $B$, compostas por suínos da raça Pietrain e Landrace, respectivamente. Para gerar as populações simuladas, foi desenvolvido um simulador em linguagem Fortran utilizando as (co)variâncias dos valores genéticos e as taxas produtivas e reprodutivas obtidas das populações $A$ e B. Dois arquivos de dados foram criados. O primeiro continha o pedigree dos 10 anos anteriores, com 21.906 e 251.343 animais nas populações $A$ e B, respectivamente. O segundo incluiu os valores genéticos para idade para atingir 110 Kg de peso vivo, espessura de toucinho e conversão alimentar, para ambas as populações; profundidade do músculo longissimus dorsi, apenas para a população $A$; e número de leitões vivos no $5^{\circ}$ dia de vida por parto, apenas para a população B. Três cenários foram simulados com dez gerações, variando as restrições quanto ao número de irmãos completos e meios-irmãos selecionados para machos e fêmeas, com 30 repetições por geração e cenário. Independentemente da estratégia de acasalamento utilizada em um núcleo de produção fechada, há aumento nos níveis de endogamia. Aumentos de endogamia são maiores em populações de menor tamanho efetivo. Restrições ao número de irmãos completos e meios-irmãos selecionados são eficazes na redução de incrementos na endogamia. A restrição de no máximo dois irmãos completos, três meios-irmãos para machos e três irmãs completas para fêmeas fornece os maiores ganhos genéticos.

Palavras-chave: estratégias de seleção, irmãos completos, meios-irmãos, raça Landrace, raça Pietrain.

\section{INTRODUCTION}

As with other species, pig breeding programs work with closed elite herds, which makes inbreeding an important issue. In general, geneticists are aware of the depressive effect of inbreeding and do not deliberately use this practice with their herds. When they do, they try to keep it at controlled levels and rates.

Process of selection based on genetic evaluation using animal models, whose accuracy is increased through the addition of information of parents, elevates chances of co-selection of relatives, which leads to increased inbreeding and a reduction 
of genetic variation (WOOLLIAMS et al., 2015). As a result, breeding process can be negatively affected by inbreeding depression, also defined by a decrease in the phenotypic value of traits as a direct consequence of inbreeding (FALCONER \& MACKAY, 1996).

The genetic basis of inbreeding depression is explained by two main hypotheses: the first is the partial dominance hypothesis presuming that, under directional dominance, a large number of recessive/partially recessive genes cause inbreeding depression (CROW, 1952). Thus, because inbreeding increases the frequency of homozygotes, the deleterious recessive alleles, which are present in the heterozygotes, express themselves in a higher proportion. The second hypothesis, of over dominance, states that heterozygotes are superior to both homozygotes and the decreased frequency of heterozygotes due to inbreeding reduces the opportunity of expression of this heterozygotes (CHARLESWORTH \& CHARLESWORTH, 1999). In addition to these two hypotheses, a third one has been proposed by TEMPLETON \& READ (1994) whereby inbreeding depression is a consequence of the disruption of the epistatic interaction between the loci, caused by inbreeding.

One of the many ways of controlling levels of inbreeding in herds is determining the critical level of relatedness allowed in mating, selection inside the families, and the maximum number of offspring per male or female to be selected (KRISTENSEN \& SØRENSEN, 2005).

The objective of this study was to evaluate, through data simulation, the impact of restricting the number of sons and daughters per male or female on the inbreeding levels of the herd and the genetic gain obtained in a swine breeding program.

\section{MATERIAL AND METHODS}

Data of real populations A (Pietrain) and B (Landrace), used in this study, originated from two lineages from farms in west Santa Catarina State, Brazil. Active herds included 125 females and 25 males for population A and 400 females and 45 males for population $B$.

The management strategy adopted in the populations used in this study is described as follows: at birth, piglets were individually identified, weighed, and injected with iron dextran. Litters were equalized by number and weight class between female pigs that gave birth in the same week. Piglets were kept in the nursery phase until 10 weeks of age, when males were separated and raised in individual pens and females were raised in collective pens that housed 12 animals. Live weight, backfat thickness, and longissimus dorsi muscle depth were measured when animals finished the performance test (at approximately 20 weeks of age). Feed conversion was measured only in males.

To generate simulated populations, a Fortran-language simulator was developed using the (co)variances of the breeding values and the productive and reproductive rates and means obtained from the real populations, composed of the animals selected in the year 2014 (Generation 0). These simulated populations also used information on restrictions regarding the number of services and the number of animals selected in each generation. Two data files were created. The first contained the pedigree of the animals in the previous ten years, with 21,906 animals in population A and 251,343 animals in population B. The second file contained the estimated breeding values for age (AGE110), backfat thickness (BFT110), and feed conversion (FC110), all of which were adjusted for 110 $\mathrm{kg}$ live weight, for the two populations; longissimus dorsi muscle depth adjusted for $110 \mathrm{~kg}$ live weight (D110), for population A only; and number of live piglets at the 5th day of life per farrowing (LP5), for population B only.

Estimates of the co(variance) components of the real populations were obtained using REMLF90 software (MISZTAL, 2002), which adopts the maximum expectation of the restricted maximum likelihood function (REML). The convergence criterion employed, defined by the mean square of the differences between consecutive solutions, was $1 \times 10 \mathrm{e}-11$. Predicted heritability and breeding values were obtained from these variance components using the multi-trait animal model for AGE110, BFT110, FC110, and D110, or the single-trait model for LP5. The model below was adopted for the multi-trait analyses involving the real populations:

$y=X \beta+Z \mu+e$

in which $y=$ vector of observations; $\beta=$ vector of fixed effects of contemporary group (CG) (animals born in the same conditions of production unit, lineage, sex, year, and week, and which finished the performance test in the same week); $\mu=$ vector of random direct additive genetic effects; $e=$ vector of random residual effects; and $X$ and $Z=$ incidence matrices for the fixed and random effects, respectively. For the single-trait analyses, the model used is given below:

$y=X \beta+Z_{1} \mu+Z_{2} p e+e$

in which $y=$ vector of observations; $\beta=$ vector of fixed effects of CG (animals born in the same conditions of production unit, lineage, sex, year, and week) and order of birth (from one to five farrowing); $\mu$ = vector 
of random direct additive genetic effects; $p e=$ vector of random permanent environmental genetic effects; $e=$ vector of random residual effects; $X, Z_{1}$, and $Z_{2}=$ incidence matrices for the fixed, random, and permanent environmental effects, respectively.

From the animals of generation $\mathrm{G}_{0}$, the simulator applied post-selection losses and performed random mating by means of a uniform distribution $\mathrm{U} \sim(0,1)$, considering the following imposed restrictions: number of mating per animal ( 25 per male and 5 per female), relatedness between the couples (maximum $10.7 \%$ in $\mathrm{G}_{0}$ plus $1 \%$ per generation), number of farrowing per female $(50 \%$ of female with one farrowing, $80 \%$ until three farrowing, $100 \%$ until five farrowing), and farrowing rate (91\%). Coefficients of relationship between the animals used in the mating restrictions were calculated using par 3.f software (BOICHARD, 2002). From each successful mating, the number of piglets at the end of the performance test per farrowing (NFT) in generation $1\left(\mathrm{G}_{1}\right)$ was calculated, considering data such as number of piglets born, mortality rates in the farrowing, maternity, and nursery phases and performance test, besides other losses. Based on real populations, the mean (MEANNFT) and the standard deviation (SDNFT) of the NFT were calculated and used to calculate the NFT of each successful mating, as follows: NFT $=$ MEANNFT $+z^{*}$ SDNFT, in which $z=$ random value obtained from a normal standard distribution $-\mathrm{N} \sim(0,1)$.

According to VAN DER WERF \& DE BOER (1990), the breeding value of each animal is calculated by the following equation:

$a_{i}=\frac{1}{2} a_{s_{i}}+\frac{1}{2} a_{d_{i}}+\phi_{i}$

in which $a_{s_{i}}$ and $a_{d_{i}}$ correspond to the boar and sow breeding values for trait $i$, respectively; and $\phi_{i}$ results from Mendelian segregation, which is independent of $a_{s_{i}}$ and $a_{d_{i}}$ (BULMER, 1971). The variance of $\phi_{i}$ can be described as follows:

$\phi_{i}=\frac{1}{2}\left[1-\frac{1}{2}\left(F_{s}+F_{d}\right)\right] \sigma_{a}^{2}$

in which $F_{s}$ and $F_{d}$ correspond to the inbreeding coefficients of boar and sow, respectively.

In the simulation in question, the variance component used was the co(variance) matrix of the breeding values of the four traits $\left(G_{a}\right)$ obtained from each real population. Additive genetic value $\left(\alpha_{i}\right)$ of each animal of the next generation was obtained as follows:

$$
a_{i}=\frac{1}{2} a_{s_{i}}+\frac{1}{2} a_{d_{i}}+z \sqrt{\frac{1}{2}\left[1-\frac{1}{2}\left(F_{s}+F_{d}\right)\right] G_{a}}
$$

in which $Z$ represents a random value obtained from a normal standard distribution $-\mathrm{N} \sim(0,1)$.
After the $\alpha_{i}$ values were generated for the $G_{1}$ animals at the end of the performance test, the animals were classified according to a selection index that grouped the four traits (AGE110, BFT110, FC110, and D110, or LP5) and a random loss rate was applied in the selection. Subsequently, a fixed number of animals was selected (corresponding to approximately $140 \%$ of the annual turnover for females and to $200 \%$ for males) considering the fulland half-sibs restrictions, for males and females. Using the information on selected animals in $G_{1}$, the entire process was repeated for ten generations.

Three scenarios were simulated with varying numbers of full- and half-sibs selected, for males and females (Table 1). The values used in the simulations were the result of previous experience with real populations and varied according to their effective size.

According to CARNEIRO et al. (2008), in simulation processes with only one repetition, genetic drift affects genetic gain, especially in populations with a small effective size, compromising the comparison of genetic evaluation methodologies. Use of 30 replicates in the simulation process makes it possible to obtain consistent data in comparative studies of different genetic evaluation methodologies that use simulations. In this way, for each simulated scenario, 30 replicates were used per generation.

Efficiency of each scenario was estimated considering the control of increments in the mean inbreeding of the herds, as follows: $\Delta F_{t}=\left(F_{t}-F_{t-1}\right) /\left(1-F_{t-1}\right)$ in which $t=$ generation number; and $F_{t}=$ mean inbreeding coefficient for generation $t$ (WRIGHT, 1922). Additionally, genetic gains were calculated per generation for each trait as shown below:

$$
G G_{t}=V G F T_{t}-V G F T_{t-1}
$$

in which $t=$ generation number; $G G_{t}=$ genetic gain in generation $t$; and $V G F T_{t}=$ average of the animal values at the end of the performance test in generation $t$.

\section{RESULTS AND DISCUSSION}

The effective sizes of populations A and B were 83 and 162, respectively. Average inbreeding coefficient $\left(F_{a}\right)$ for generation $0\left(\mathrm{G}_{0}\right)$ was higher for population A (0.0399) than for population B (0.0235). In all scenarios, there was an increase in inbreeding levels for both populations, with higher values observed when restrictions were milder (scenario 3; Figure 1).

The mean increase in the inbreeding coefficient $\left(\Delta F_{a}\right)$ considering the three simulated scenarios (Table 2) was slightly lower for population 
Table 1 - Number of full and half-sibs allowed among those selected according to the sex and population for each simulated scenario.

\begin{tabular}{|c|c|c|c|c|}
\hline \multirow[t]{2}{*}{ Scenario } & \multicolumn{2}{|c|}{-------------------------------Males----------------------- } & \multicolumn{2}{|c|}{-----------------------------Females----------------------- } \\
\hline & Number of full-sibs & Number of half-sibs & Number of full-sibs & Number of half-sibs \\
\hline \multicolumn{5}{|c|}{ 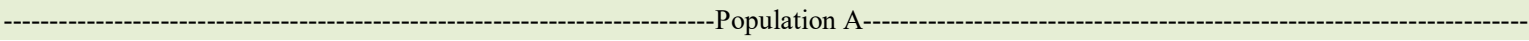 } \\
\hline 1 & 1 & 2 & 2 & 15 \\
\hline 2 & 2 & 3 & 3 & 15 \\
\hline 3 & 3 & 4 & 4 & 21 \\
\hline \multicolumn{5}{|c|}{ - } \\
\hline 1 & 1 & 2 & 2 & 32 \\
\hline 2 & 2 & 3 & 3 & 32 \\
\hline 3 & 3 & 4 & 4 & 36 \\
\hline
\end{tabular}

B (0.0058) compared with population A (0.0061). The less stringent constraints imposed in scenarios 2 and 3 produced inbreeding coefficients approximately $15 \%$ and $25 \%$ higher than that observed in scenario 1.

The average increase in inbreeding levels from generations 0 to 10 , for populations $\mathrm{A}$ and $\mathrm{B}$, confirmed the results reported by other researchers
(VAN DER WERF \& DE BOER, 1990; BREDA et al., 2004; KRUPA et al., 2015), who stated that populations with small effective sizes $(\mathrm{Ne})$ presented the highest inbreeding coefficients. This is explained by the higher probability of mating between related individuals in these populations, compared with those with a higher Ne. MELKA \& SCHENKEL (2010), in

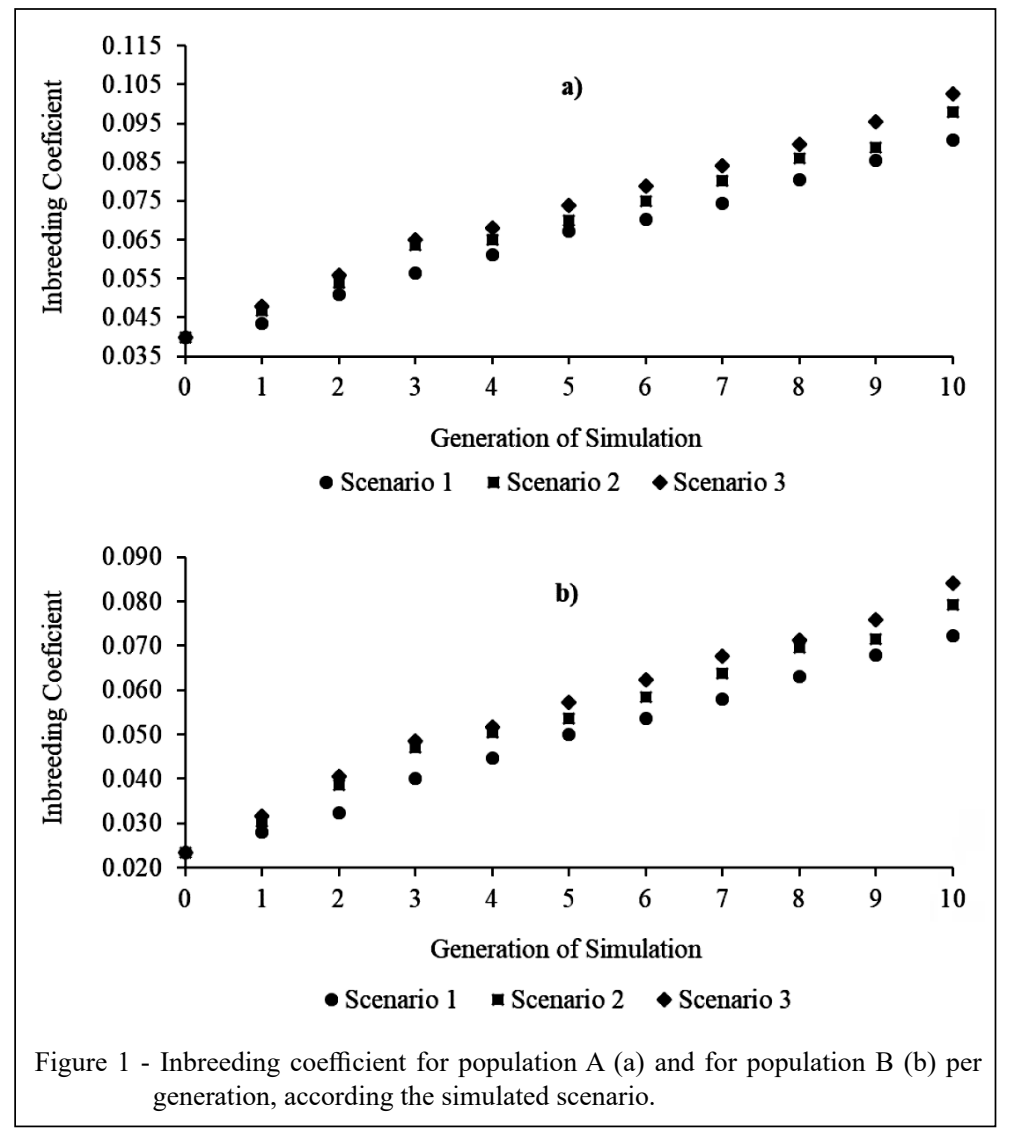

Ciência Rural, v.49, n.7, 2019. 
Table 2 - Increment in inbreeding coefficient per generation and standard error, according the simulated scenarios, for the populations A and $\mathrm{B}$

\begin{tabular}{|c|c|c|c|c|c|c|}
\hline \multirow[t]{2}{*}{ Generation } & \multicolumn{3}{|c|}{ 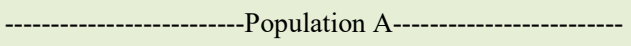 } & \multicolumn{3}{|c|}{ 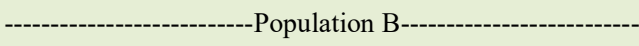 } \\
\hline & Scenario 1 & Scenario 2 & Scenario 3 & Scenario 1 & Scenario 2 & Scenario 3 \\
\hline 1 & $0.0015 \pm 0.0009$ & $0.0072 \pm 0.0003$ & $0.0084 \pm 0.0003$ & $0.0046 \pm 0.0002$ & $0.0071 \pm 0.0003$ & $0.0083 \pm 0.0003$ \\
\hline 2 & $0.0099 \pm 0.0006$ & $0.0076 \pm 0.0003$ & $0.0084 \pm 0.0003$ & $0.0046 \pm 0.0003$ & $0.0085 \pm 0.0004$ & $0.0093 \pm 0.0003$ \\
\hline 3 & $0.0060 \pm 0.0004$ & $0.0101 \pm 0.0006$ & $0.0095 \pm 0.0003$ & $0.0080 \pm 0.0006$ & $0.0089 \pm 0.0004$ & $0.0083 \pm 0.0003$ \\
\hline 4 & $0.0047 \pm 0.0003$ & $0.0014 \pm 0.0005$ & $0.0033 \pm 0.0003$ & $0.0046 \pm 0.0003$ & $0.0035 \pm 0.0003$ & $0.0032 \pm 0.0003$ \\
\hline 5 & $0.0067 \pm 0.0005$ & $0.0056 \pm 0.0002$ & $0.0061 \pm 0.0001$ & $0.0097 \pm 0.0008$ & $0.0034 \pm 0.0003$ & $0.0060 \pm 0.0001$ \\
\hline 6 & $0.0030 \pm 0.0006$ & $0.0052 \pm 0.0003$ & $0.0056 \pm 0.0002$ & $-0.0002 \pm 0.0008$ & $0.0052 \pm 0.0002$ & $0.0055 \pm 0.0001$ \\
\hline 7 & $0.0046 \pm 0.0004$ & $0.0057 \pm 0.0002$ & $0.0057 \pm 0.0001$ & $0.0045 \pm 0.0002$ & $0.0056 \pm 0.0002$ & $0.0056 \pm 0.0001$ \\
\hline 8 & $0.0065 \pm 0.0005$ & $0.0062 \pm 0.0002$ & $0.0060 \pm 0.0001$ & $0.0053 \pm 0.0004$ & $0.0061 \pm 0.0002$ & $0.0037 \pm 0.0002$ \\
\hline 9 & $0.0054 \pm 0.0003$ & $0.0032 \pm 0.0003$ & $0.0063 \pm 0.0001$ & $0.0053 \pm 0.0003$ & $0.0020 \pm 0.0003$ & $0.0051 \pm 0.0001$ \\
\hline 10 & $0.0058 \pm 0.0003$ & $0.0097 \pm 0.0005$ & $0.0081 \pm 0.0003$ & $0.0046 \pm 0.0003$ & $0.0085 \pm 0.0004$ & $0.0090 \pm 0.0003$ \\
\hline Mean & $0.0054 \pm 0.0004$ & $0.0062 \pm 0.0003$ & $0.0067 \pm 0.0002$ & $0.0051 \pm 0.0003$ & $0.0059 \pm 0.0003$ & $0.0064 \pm 0.0002$ \\
\hline
\end{tabular}

Canada, reported a $F_{a}$ of 0.18 for the Hampshire breed $(\mathrm{Ne}=14)$, and 0.12 for the Lacombe breed $(\mathrm{Ne}=36)$, while for the Duroc $(\mathrm{Ne}=72)$ and Landrace $(\mathrm{Ne}=125)$ breeds, these values did not exceed 0.06. Similarly, WELSH et al. (2010) reported values ranging from 0.032 to 0.078 for purebred pigs in the United States of America, with $\mathrm{Ne}$ ranging from 74 to 113. One aspect that must be considered when comparing the $F_{a}$ of different real populations is the number of generations used to estimate this parameter, since a reduced number of generations tend to underestimate the $F_{a}$. However, in the comparisons above, with the possibly low underestimated $F_{a}$ values reported by MELKA \& SCHENKEL (2010), the authors used 13 and 11 real generations to estimate this parameter for the respective Duroc and Landrace breeds.

The effective population size is one of the factors that most influence inbreeding, with smaller inbreeding increments occurring in populations with a larger effective size. However, the main restriction to the use of larger populations is the high cost of maintaining the population. In this scenario, it is desirable that the population have an effective size that provides the best results, optimizing the costbenefit ratio. MEUWISSEN \& WOOLLIAMS (1994) and KRISTENSEN \& SØRENSEN (2005) recommended that the herds should have an effective size of 50 or more, representing an increment of inbreeding $<1 \%$, to maintain deleterious mutations under control. These authors claimed that this size is enough to avoid inbreeding depression in the short term. Conversely, FRANKLIN \& FRANKHAM (1998) reported that for the maintenance of genetic variance in the long term, an effective size greater than 500 is required.

The highest inbreeding values in this study occurred when the restrictions were lighter, and these results were similar to those obtained by BREDA et al. (2004), who observed that not even the exclusion of mating between full-sibs avoids the medium- and long-term accumulation of inbreeding.

The increase from 0.0051 to 0.0067 in the inbreeding coefficients in this study is within the parameters indicated by FAO (2000), which suggested that $\Delta F_{a}$ should not exceed 0.01 . However it is higher than the values reported by KRUPA et al. (2015) for purebred pig populations in Czech Republic (0.0017 to 0.0056 ), with $\mathrm{Ne}$ ranging from 29 to 225 . Despite not reporting selection intensity values, those authors emphasized the effect of selection intensity practiced in each simulation as a factor of great impact on inbreeding increments. Scenarios simulated by PEREIRA FILHO (2005) considering different mating conditions led to a 0.005 increase in $\Delta F_{a}$ for a population with a $\mathrm{Ne}$ equal to 120 and compensatory mating, using selection intensities of 1.51 for males and 0.80 for females. The average selection intensity values used in the present study were 2.20 and 1.55 for males and females, respectively, in population B; and 1.97 and 1.40 for males and females, respectively, in population $\mathrm{A}$.

According to KRISTENSEN \& SØRENSEN (2005) and WILLOUGHBY et al. (2015), one of the most important consequences of increasing in $\Delta F_{a}$ is the reduction of genetic variance and; consequently, of the potential genetic gains of populations. 
In population $\mathrm{A}$, the variance of genetic values for feed conversion adjusted for $110 \mathrm{~kg}$ live weight (FC110) decreased by $4.88 \%$, on average, up to the 10th generation $\left(\mathrm{G}_{10}\right)$, while for population $\mathrm{B}$ it increased by $2.18 \%$, on average, up to $\mathrm{G}_{10}$. Comparing the variance of the breeding values for FC110 in the simulated scenarios, in population A, scenario 2 obtained a $2.5 \%$ lower value, whereas scenario 3 resulted in a value $3.0 \%$ lower than scenario 1 on the average of the generations. A similar trend was observed for population $\mathrm{B}$, where values were $0.5 \%$ and $1.0 \%$ lower, respectively, for scenarios 2 and 3, compared with scenario 1.

According to KRISTENSEN \& SØRENSEN (2005), the effects of the levels and increments of inbreeding on genetic variance are widely reported with a negative correlation. However, at low inbreeding levels, the predictability of this correlation is lower, depending, for example, on the intensity of selection and on the genetic basis of the trait in question. Experimental and theoretical results showed that additive genetic variance can increase with inbreeding in some circumstances such as those reported by those authors, when they simulated two scenarios in a population with a $\mathrm{Ne}$ equal to 50 . In the first scenario, they simulated the non-additive genetic variance as $40 \%$ of the additive genetic variance, representing production traits, and, in the second scenario, the non-additive variance was equal to the additive variance, representing fertility traits. Until $\mathrm{G}_{10}$, in the first scenario, the additive genetic variance had a slight decrease, while in the second, this variance increased. After $\mathrm{G}_{10}$, additive genetic variance reduced by 30 to $40 \%$ until $\mathrm{G}_{100}$. Nevertheless, the authors reported that, in this long- term horizon, variances can deviate considerably from the expected/simulated behavior.

Estimated heritability were 0.11 for number of live piglets at the 5th day of life per farrowing (LP5), for population B; and 0.45 and 0.37 for FC110 for populations A and B, respectively. These results agreed with those reported by YAMAKI (2009), which estimated heritability for CA110 equal to 0.48 and 0.33 , respectively, for populations of the Pietrain and Landrace breeds. Likewise, NSIF-FS3 (2002) reported heritability of 0.10 for number of live-born piglets, 0.15 for weaning weight adjusted for 21 days of age and 0.30 for days to reach 250 pounds of live weight $(113.4 \mathrm{Kg})$ and ROTHSCHILD \& BIDANEL (1998), estimated heritability of 0.09 for number of live birth piglets and 0.17 for weaning weight adjusted for 21 days of age. However, studies by HERMESCH et al. (2002) and HOQUE et al. (2007), with Duroc males, estimated heritability of lesser magnitude than those obtained in this study, of 0.15 and 0.27 for feed conversion, respectively.

Mean values of genetic gains for FC110 in populations $\mathrm{A}$ and $\mathrm{B}$ were -0.077 and $-0.036 \mathrm{~kg}$ / $\mathrm{kg}$, respectively (Table 3 ). Considering the mean genetic gains obtained in the ten generations for FC110, scenarios 2 and 3 were $3.34 \%$ and $3.67 \%$ more efficient, respectively, than scenario 1 , for population $\mathrm{A}$. The same was true for population $\mathrm{B}$, where scenarios 2 and 3 were respectively $4.12 \%$ and $3.77 \%$ more efficient than scenario 1 (Table 3).

Lower restrictions imposed in scenarios 2 and 3 for FC110 promoted higher genetic gains. Similar results were observed for LP5, in population B (Table 4), where the mean genetic

Table 3 - Genetic gain for feed conversion adjusted for $110 \mathrm{~kg}$ live weight per generation, according to the simulated scenarios, for the populations A and B

\begin{tabular}{|c|c|c|c|c|c|c|}
\hline \multirow[t]{2}{*}{ Generation } & \multicolumn{3}{|c|}{--------------------------Population A------------------------- } & \multicolumn{3}{|c|}{ 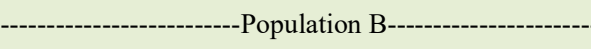 } \\
\hline & Scenario 1 & Scenario 2 & Scenario 3 & Scenario 1 & Scenario 2 & Scenario 3 \\
\hline 1 & -0.0765 & -0.0787 & -0.0802 & -0.0351 & -0.0368 & -0.0375 \\
\hline 2 & -0.0742 & -0.0779 & -0.0777 & -0.0367 & -0.0378 & -0.0371 \\
\hline 3 & -0.0736 & -0.0750 & -0.0753 & -0.0357 & -0.0365 & -0.0365 \\
\hline 4 & -0.0752 & -0.0758 & -0.0757 & -0.0345 & -0.0358 & -0.0374 \\
\hline 5 & -0.0742 & -0.0768 & -0.0766 & -0.0355 & -0.0366 & -0.0366 \\
\hline 6 & -0.0727 & -0.0773 & -0.0776 & -0.0350 & -0.0363 & -0.0356 \\
\hline 7 & -0.0759 & -0.0775 & -0.0765 & -0.0356 & -0.0371 & -0.0368 \\
\hline 8 & -0.0752 & -0.0781 & -0.0768 & -0.0357 & -0.0371 & -0.0369 \\
\hline 9 & -0.0746 & -0.0780 & -0.0777 & -0.0353 & -0.0365 & -0.0366 \\
\hline 10 & -0.0757 & -0.0786 & -0.0780 & -0.0354 & -0.0365 & -0.0358 \\
\hline Mean & -0.0748 & -0.0773 & -0.0772 & -0.0354 & -0.0367 & -0.0366 \\
\hline
\end{tabular}


Table 4 - Genetic gain for number of live piglets at the $5^{\text {th }}$ day of life, per farrowing per generation, according to the simulated scenarios, for the population $\mathrm{B}$.

\begin{tabular}{lccc}
\hline Generation & & & \\
& & & Scenario 3 \\
1 & Scenario 1 & Scenario 2 & 0.3843 \\
2 & 0.3287 & 0.3707 & 0.3322 \\
3 & 0.3304 & 0.3343 & 0.3204 \\
4 & 0.3174 & 0.3208 & 0.3256 \\
5 & 0.3155 & 0.3204 & 0.3172 \\
6 & 0.3106 & 0.3212 & 0.3277 \\
7 & 0.3196 & 0.3297 & 0.3131 \\
\hline 8 & 0.3155 & 0.3234 & 0.3237 \\
10 & 0.3142 & 0.3308 & 0.3314 \\
\hline Mean & 0.3093 & 0.3254 & 0.3244 \\
\hline
\end{tabular}

gains were $4.12 \%$ and $3.77 \%$ higher, respectively, than in scenario 1 .

The difference observed in the genetic gain for FC110 between populations A and B may have been caused by the fact that the animals were selected based on a selection index composed of four characteristics. In population A, the highest economic weight was assigned to $\mathrm{FC} 110$, while in population $\mathrm{B}$, the highest economic weight was assigned to LP5, whose variance was reduced, on average, by $3.11 \%$ until $\mathrm{G}_{10}$. The highest losses of genetic variability were observed for population A, which corroborates literature studies reporting higher variability losses due to increasing inbreeding in populations with lower $\mathrm{Ne}$ (WILLOUGHBY et al., 2015).

The genetic gains estimated in this study for $\mathrm{FC} 110$ are higher than those reported by DO et al. (2013) for the Landrace (approximately -0.027 $\mathrm{kg} / \mathrm{kg}$ each year) and Large White (approximately $-0.030 \mathrm{~kg} / \mathrm{kg}$ each year) breeds, in Denmark; by TRIBOUT et al. (2010), for the Large White breed in France $(-0.300 \mathrm{~kg} / \mathrm{kg}$ from 1977 to 1996$)$; and by ORLANDO et al. (2016), for pigs of PIC genetics, on the average of the previous three years $(-0.020 \mathrm{~kg} /$ $\mathrm{kg}$ ), in the commercial sector.

The genetic gains for LP5 in this study are higher than those reported by BOLET et al. (2001) for the first and the second farrowing of the Large White breed in France (0.086 and 0.078, respectively) and by NIELSEN et al. (2014) for the Danish Landrace and Yorkshire breeds from 2004 to 2010 (1.7 and 1.9, respectively). BOLET et al. (2001) affirmed that a significant issue in reproductive genetic evaluation is the genetic model assumed, because it is wellknown that ignoring dominance for traits known to exhibit such effects, like litter size in pigs, leads to an overestimation of responses. However, as these authors show, bias is reduced when the animal model included a litter effect, for estimating both heritability and breeding values, as was done in this study.

\section{CONCLUSION}

There is an increase in inbreeding levels in closed production units regardless of the mating strategy used. Inbreeding increases are larger in populations of smaller effective size. Restrictions in the number of full-sibs and half-sibs selected are effective in reducing the inbreeding increments. Restriction to a maximum of two full-sibs and three half-sibs for males and three full sisters for females provided the highest genetic gains.

\section{ACKNOWLEDGEMENTS}

We are grateful to Company BRF S/A and its Genetic Breeding Program for Pigs, for providing the data and for enabling the execution of the present study. To the Laboratório de Melhoramento Animal and the Programa de Pós-Graduação em Zootecnia of the Universidade Federal de Santa Maria, for the opportunity. Especially to Marcelo Silva de Freitas, for the development of the simulator employed in this research.

\section{DECLARATION OF CONFLICT OF INTERESTS}

The authors declare no conflict of interest. The founding sponsors had no role in the design of the study; in the 
collection, analyses, or interpretation of data; in the writing of the manuscript, and in the decision to publish the results.

\section{AUTHORS' CONTRIBUTIONS}

Conceptualization: J.S. Lopes and M.S. Freitas. Data curation: M.S. Freitas. Software: M.S. Freitas. Supervision: P.R.N. Rorato and F.C. Breda. Visualization: A.M. Prestes, D.A. Garcia and M.M. Oliveira. Writing-original draft: J.S. Lopes. Writingreview \& editing: J.S. Lopes.

\section{REFERENCES}

BOICHARD, D. PEDIG: a fortran package for pedigree analysis suited for large populations. In 7th World Congress on Genetics Applied to Livestock Production, Proceedings... Montpellier, France. 2002

BOLET, G. et al. Selection for litter size in pigs. II. Efficiency of closed and open selection lines. Genetic Selection Evolution, v.33, p.515-528, 2001. Available from: <https://gsejournal. biomedcentral.com/articles/10.1186/1297-9686-33-5-515> Accessed: Jan. 10, 2017. doi: 10.1186/1297-9686-33-5-515.

BREDA, F. C. et al. Endogamia e limite de seleção em populações selecionadas obtidas por simulação. Revista Brasileira de Zootecnia, v.33, p.2017-2025, 2004. Available from: $<$ http://www.scielo.br/scielo.php?script=sci arttext\&pid $=$ S1516-35982004000800013 $>$. Accessed: Jan. 10, 2017. doi: 10.1590/S1516-35982004000800013.

BULMER, M. The effect of selection on genetic variability. The American Naturalist, v. 105, p.201-211, 1971. Available from: <http://www.jstor.org/stable/2459550>. Accessed: Feb. 18, 2016

CARNEIRO, P. L. S. et al. Comparação de metodologias de seleção sob oscilação genética. Arquivo Brasileiro de Medicina Veterinária e Zootecnia, v.60, p.932-942, 2008 Available from: <http://www.scielo.br/scielo.php?script=sci abstract\&pid $=$ S0102-09352008000400024\&lng $=$ en\& $\mathrm{nrm}=\mathrm{i}$ so\&tlng=pt $>$. Accessed: Feb. 12, 2016. doi: 10.1590/S010209352008000400024.

CHARLESWORTH, B.; CHARLESWORTH, D. The genetic basis of inbreeding depression. Genetical Research, v.74, p.329 340, 1999. Available from: <https://www.ncbi.nlm.nih.gov/ pubmed/10689809>. Accessed: Feb. 18, 2016.

CROW, J. F. Dominance and overdominance. In: Heterosis Gowen, J. W., ed. Iowa State College Press, Ames, IA, USA. p.282-294, 1952.

DO, D. N. et al. Genetic parameters for different measures of feed efficiency and related traits in boars of three pig breeds. Journal of Animal Science, v.91, p.4069-4079, 2013. Available from: $<\mathrm{https}: / /$ academic.oup.com/jas/article-abstract/91/9/4069/4717231>. Accessed: Jan. 13, 2017. doi: 10.2527/jas.2012-6197.

FALCONER, D. S.; MACKAY, T. F. Introduction to quantitative genetics. Pearson Education Limited, Harlow. 1996.

FAO. Secondary guidelines for development of farm animal genetic resources management plans. Management of small populations at risk. FAO, Rome, Italy. 2000.
FRANKLIN, I.; FRANKHAM, R. How large must populations be to retain evolutionary potential? Animal Conservation, v.1, p.69-70, 1998. Available from: <https://zslpublications.onlinelibrary.wiley. com/doi/abs/10.1111/j.1469-1795.1998.tb00228.x>. Accessed: Jan. 23, 2017. doi: 10.1111/j.1469-1795.1998.tb00228.x.

HERMESCH, S. et. al. Feeding level influences genetic parameters for performance traits in pigs. In 7th World Congress on Genetics Applied to Livestock Production, Proceedings... Montpellier, 2002.

HOQUE, M. A. et al. Genetic parameters for measures of feed efficiency of boars and their genetic relationships with its component traits in Duroc pigs. Journal of Animal Science, v.85, p.1873-1879, 2007. Available from: <https://onlinelibrary.wiley. com/doi/abs/10.1111/j.1439-0388.2007.00650.x>. Accessed: Jan. 13, 2017. doi: 10.1111/j.1439-0388.2007.00650.x.

KRISTENSEN, T. N.; SØRENSEN, A. C. Inbreedinglessons from animal breeding, evolutionary biology and conservation genetics. Animal Science, v.80, p.121-133, 2005. Available from: <https://www.cambridge.org/core/journals/ animal-science/article/inbreeding-lessons-from-animalbreeding-evolutionary-biology-and-conservation-genetics/ A67B0122E2816C796EB06AD913A60353>. Accessed: Jan. 23, 2017. doi: 10.1079/ASC41960121.

KRUPA, E. et al. Evaluation of inbreeding and genetic variability of five pig breeds in Czech Republic. Asian-Australasian Journal of Animal Sciences, v.28, p.25-36, 2015. Available from: $<$ https:// www.ncbi.nlm.nih.gov/pmc/articles/PMC4283186/>. Accessed: Mar. 13, 2016. doi: 10.5713/ajas.14.0251.

MELKA, M. G.; SCHENKEL, F. Analysis of genetic diversity in four Canadian swine breeds using pedigree data. Canadian Journal of Animal Science, v.90, p.331-340, 2010. Available from: $<$ https://www.nrcresearchpress.com/doi/10.4141/CJAS10002\#. XOsduaJKjIU>. Accessed: Feb. 13, 2017. doi: 10.4141/CJAS10002.

MEUWISSEN, T.; WOOLLIAMS, J. Effective sizes of livestock populations to prevent a decline in fitness. Theoretical and Applied Genetics, v.89, p.1019-1026, 1994. Available from: $<$ https://www.ncbi.nlm.nih.gov/pubmed/24178119>. Accessed: Jun. 25, 2016. doi: 10.1007/BF00224533.

MISZTAL, I. BLUPF90 family of programs. 2002. Available from: <http://nce.ads.uga.edu/ ignacy/numpub/blupf90/docs/ remlf90.pdf $>$. Accessed: Oct. 12, 2012.

NIELSEN, B. et al. Selection for increased number of piglets at d 5 after farrowing has increased litter size and reduced piglet mortality. Journal of Animal Science, v.91, p.25752582, 2014. Available from: <https://www.ncbi.nlm.nih.gov/ pubmed/23508021>. Accessed: Jul. 26, 2016. doi: 10.2527/ jas.2012-5990.

NSIF-FS3. 2002. Genetic parameters and their use in swine breeding. National Swine Improvement Federation. Available from: <http://www.nsif.com>. Accessed: Nov. 11, 2009.

ORLANDO, U. et al. Genetic improvement and nutrition trends. In World Nutrition Forum, Proceedings... Vancouver, Canada, p.177-181, 2016.

PEREIRA FILHO, J. 2005. Efeito do tamanho efetivo e de sistemas de acasalamento no incremento de endogamia em

Ciência Rural, v.49, n.7, 2019. 
populações sob seleção, utilizando-se simulação. Universidade Federal de Viçosa.

ROTHSCHILD, M. F.; BIDANEL, J. P. Biology and genetics of reproduction. In: The genetics of the pig, CAB International, Wallingford, 1998

TEMPLETON, A. R.; READ, B. Inbreeding: one word, several meanings, much confusion. Exs, v.68, p.91-105, 1994. Available from: $<$ https://www.ncbi.nlm.nih.gov/pubmed/8032141>. Accessed: Feb. 26, 2016.

TRIBOUT, T. et al. Estimation of genetic trends in French Large White pigs from 1977 to 1998 for growth and carcass traits using frozen semen. Journal of Animal Science, v.88, p.28562867, 2010. Available from: <https:/www.ncbi.nlm.nih.gov/ pubmed/20495129>. Accessed: Jun. 21, 2016. doi: 10.2527/ jas.2009-2356.

VAN DER WERF, J. H.; DE BOER, I. J. Estimation of additive genetic variance when base populations are selected. Journal of Animal Science, v.68, p.3124-3132, 1990. Available from: <https://pdfs.semanticscholar.org/4745/ f7ed29478432d143e04ba4251a5a9c168e10.pdf $>$. Accessed: Apr. 11, 2016.
WELSH, C. S. et al. Pedigree analysis of 5 swine breeds in the United States and the implications for genetic conservation. Journal of Animal Science, v.88, p.1610-1618, 2010. Available from: $<$ https://www.ncbi.nlm.nih.gov/pubmed/20190174>. Accessed: Jul. 20, 2016. doi: 10.2527/jas.2009-2537.

WILLOUGHBY, J. R. et al. The impacts of inbreeding, drift and selection on genetic diversity in captive breeding populations. Molecular Ecology, v.24, p.98-110, 2015. Available from: $<$ https://www.ncbi.nlm.nih.gov/pubmed/25443807>. Accessed: Jun. 21, 2016. doi: 10.1111/mec.13020.

WOOLLIAMS, J. A. et al. Genetic contributions and their optimization. Journal of Animal Breeding and Genetics, v.132, p.89-99, 2015. Available from: <https://onlinelibrary.wiley. com/doi/abs/10.1111/jbg.12148>. Accessed: Feb. 19, 2017. doi: 10.1111/jbg. 12148 .

WRIGHT, S. Coefficients of Inbreeding and Relationship. The American Naturalist, v.56, p.330-338, 1922. Available from: <https://www.jstor.org/stable/2456273>. Accessed: Feb. 23, 2016.

YAMAKI, M. 2009. Impacto da restrição de dados na avaliação genética animal. Universidade Federal de Viçosa. 